\title{
Protection of stored potatoes from infestation with the potato tuber moth, Phthorimaea operculella (Zeller)(Lepidoptera: Gelechiidae) using plant powders
}

\author{
Aziza Mohamed Fouad Sharaby ${ }^{1 *}$ (iD and Sahar Baker Fallatah²
}

\begin{abstract}
Background: The potato tuber moth (PTM), Phthorimaea operculella (Zeller) (Lepidoptera: Gelechiidae), is an important storage pest of potato (Solanum tuberosum L.) in Saudi Arabia and Egypt. Infestation in the store starts mostly through freshly harvested infested tubers or through moths entering the storage facilities. Larvae mine in tubers making them unsuitable for sale and consumption. Damage increases rapidly when several generations develop during the storage period. Larvae are capable of causing damage to the crop either in the field or in the store. Biopesticides are certain types of pesticides derived from animals, plants, bacteria, and certain minerals. During the course of evolution, plants have developed, as part of their defensive mechanism, various chemical molecules, which proved a protection against insect pests, since the overall pressure of insect on plant is much more than any other herbivore. Biopesticides prepared from plants are reported to have the ability to kill or keep away the pests. They are eco-friendly. The plant products have additional advantage over synthetic insecticides, as they are biodegradable, safe to non-target organisms, leave no residues, and decrease the buildup of resistance strains of insects. Present research is conducted to evaluate the capacity of certain natural local alternative plant powders against PTM under storage conditions as attempts to providing alternative and novel strategies that can be used by both the commercial and/or small-scale potato farmers to control the pest in the store.

Methods: Twelve different plants (Zygophyllum, Solanum, Coriander, Arnoglosse, Jasmine, Senna, Colocynth, Camomile, Harmel, Geranium, Basil, and Mint) locally available in the fields of the Eastern Province of the Saudi Arabian kingdom were air-dried under a shad at ambient tropical condition. The air dried materials were grinded into fine powders and kept in tight containers until using. Potato tubers were shacked with the plant powders for a good mixing, until tubers were uniformly covered and the powders stick well to the tuber surfaces. Different dried leaves or fruits of the 12 tested plants were powdered to be used at rate of $25 \mathrm{~g}$ plant powder per $1 \mathrm{Kg}$ tubers. The experiments were distributed in a randomized complete block design. Different biological aspects of the treatments were calculated; damage index to tubers and persistence of protection to the tubers during different intervals of storage were recorded.

(Continued on next page)
\end{abstract}

\footnotetext{
* Correspondence: sharaby_aziza@yahoo.com

${ }^{1}$ Pests and Plant Protection Department Agricultural \& Biological Researches

Division, National Research Centre, Cairo, Egypt

Full list of author information is available at the end of the article
} 
(Continued from previous page)

Results: All plant powders had a reduction effect on the deposited eggs laid on the treated tubers with different degrees. The dried powders of Coriander, Clocynth, and Zygophyllum reduced egg deposition on the treated tubers than the control, followed by Jassmin, Senna, Cammomil, and Harmel. The powders of Basil and Solanum also recorded a moderate reduction in egg deposition. Zygophyllum and Coriander could protect the tubers for more than 8 weeks. All other treatments greatly minimized the number of emerged moths from the treated tubers $\left(F_{1}\right)$, as follows: Coriander = Zygophyllum (0) > Basil (17.39) > Geranium (17.85) > Cammomil (18.75) > Arnoglosse (19.32) > Jasmine (21.62) > Mint (21.69) > Harmel (52.77) > Senna and Colocynth (72.72) > Solanum (100) compared with untreated tubers (95.17). All treatments had no effects on the tuber germination.

Conclusion: The study showed that all the tested plant powders, at the rate of $25 \mathrm{~g}$ plant powder per $1 \mathrm{Kg}$ potato tubers, could protect the tubers for more than 8 weeks from PTM infestation during storage. The most potent powders were Coriander and Zygophyllum. All other powders decreased the number of the emerged adults from the treated tubers, with variable degrees, and decreased the percentage of tubers' damage index recorded. Besides, all the tested plant powders had no effects on the tubers' germination.

Keywords: Potato tuber moth, Phthorimaea operculella, Plant powders, Tuber protection, Biopesticides,

\section{Background}

The potato tuber moth (PTM), Phthorimaea operculella (Zeller)(Lepidoptera: Gelechiidae), is a very important pest of potato crop (Solanum tuberosum L.) and other solanaceous plants in fields and warehouses in Saudi Arabia and Egypt. PTM infestation in stores causes yield losses up to $100 \%$ (Rondon 2010). Infestation in the stores starts mostly through freshly harvested infested tubers or through moths entering the storage facilities. Larvae mine in tubers making them unsuitable for sale and consumption. The damage increases rapidly when several generations develop during the storage period. Larvae are capable of causing damage on potato crop either in the field or in the stores. Synthetic chemical pesticides have been used for many years to control agricultural insect pests including those that damage durable food crops in storage. However, considerable problem may arise from the continuous application of these insecticides, including the development of resistance by insects, pollution of environment, and hazards from handling toxic compounds (Yuan et al. 2014; Meyer- Baron et al. 2015). Thus, there is a need to develop alternatives that are cheap, locally available, easy to be prepared, and safe to be used for insect control. In many areas of the world, there are locally available materials that could be used to protect stored crops and their products against damage by insect infestations. The ancient Egyptian farmers used to cover or mix their stored crops or grains with fine ashes, obtained from the kitchen oven fire by placing these materials on the base of silo after filling directly above the stored crops. The fine-burned materials absorb the moisture of the stored substances, the waxy layer from the cuticle of the insects, and caused cuticle aberration, leading to loss of moister and finally lead to insect death. Recently, many studies indicated that some wild medicinal and ornamental plants have pesticidal properties showing antifeedant, repellent, growth regulators effects and/or toxic activities on a wide range of insect pests (Owusu 2001; Khan and Gumbs 2003 and Onu et al. 2015). Currently, plants and minerals, known in Africa and Asia, are tested as protectors for stored products and as alternatives to pesticides to avoid hazards on human beings. Sharaby (1988) recorded the sun-dried guava (Pasidium guava) and Eucalyptus (Eucalyptus globules) leaves as protectors and toxicants against the rice weevil, S. orizae, and the granary weevil, S. granaries. Guava leaves were more toxic for both insect species, while Eucalyptus had a repellency effect. Many plant species, especially from tropical regions, have the potential to be used as botanical insecticides or as font of bioactive compounds (Quignard et al. 2003; Shaalan et al. 2005). Laboratory experiments were conducted by Chandel et al. (2018) to evaluate efficiency of ten plant materials against the pulse beetle, Callosobruchus chinensis, which infested stored chickpea seeds.

This study aimed to evaluate the potential of 12 plant powders for controlling PTM, as protectors of potato tubers during storage periods or marketing, and their persistence periods in protection.

\section{Methods}

\section{Insect culture rearing}

A stock laboratory colony of PTM was initiated on potato tubers, Solanum tuberosom (Spunta). The culture was maintained in rearing wooden cages, the front and back wall cage were with fine wire gauze and the tope with a movable door, provided with a fastened sleeve cloth for insect handling. The cage floor was covered by a layer of clean sand as a site for pupation, following the method of El-Sherif (1966). Infested potato tubers, 
Table 1 List of the tested plant powders

\begin{tabular}{|c|c|c|c|}
\hline Scientific name & Common name & Family & Plant part used \\
\hline Zygophyllum coccineum & Zygophyllum & Zygophyllaceae & Leaves \\
\hline Solanum villosum & Solanum & Solanaceae & Leaves \\
\hline Coriandrum sativum & Coriander & Umbelliferea & Leaves \\
\hline Plantago albicans & Arnoglosse & Plantaginaceae & Leaves \\
\hline Jasminum grandiflorum & Jasmin & Oleaceae & Leaves and flowers \\
\hline Cassia senna & Senna & Liguminosae & Leaves \\
\hline Citrullus cucumis & Colocynth & Cucurbitaceae & Fruit \\
\hline Anthemis desrti & Camomile & Compositae & Whole plant \\
\hline Rhayza stricta & Harmel & Apocynaceae & Leaves \\
\hline Pelargonium graveolens & Geranium & Geraniaceae & Leaves \\
\hline Ocimum basilicum & Basil & Labiacae & Leaves and flowers \\
\hline Mentha virids & Mint & Labiacae & Leaves \\
\hline
\end{tabular}

obtained from the market, were placed in the rearing cages. When the pupation was completed, the cocoons were collected from the sand to be used. After emergence of the moths, fresh clean tubers were provided for oviposition and for starting the experimental cultures. The culture and all experiments were maintained in Zoology Department, Faculty of Science for Girls, Dammam, Saudi Arabia, under room conditions of $\left(27 \pm 2{ }^{\circ} \mathrm{C}\right.$ and $70 \pm 5 \%$ R.H.) at alight regime of the day 10 -h light and 14-h dark. New clean potato tubers were added every 10 days for egg deposition and to keep a continuous culture.

\section{Plant powders}

The tested plants powders indicated in Table 1 were collected from different fields at Dammam and the desert around Eastern province of Saudi Arabia. The plants were identified according the description of Migahed (1996). The collected plants were dried in a shad at room temperature $\left(27 \pm 2{ }^{\circ} \mathrm{C}\right)$ for some days; the dried plant parts were pulverized in fine powders with the aid of electric grinder and sieved. The obtained powders were stored in plastic bags in a refrigerator at $4{ }^{\circ} \mathrm{C}$ till be used in the experiments.

\section{Efficiency of the plant powders}

One kilogram of potato tubers, submerged and allowed to dry, was treated by $(25 \mathrm{~g})$ of the plant powders $w / w$ (Raman and Booth 1986, shacked for a good mixing, until tubers were uniformly covered and the powders stick well to the tuber surfaces. The treated tubers were then distributed into five glass jars (2 L) capacity; six newly emerged moths were chosen from the stock culture $\left(3 \bigcirc+3{ }^{\lambda}\right)$, introduced inside each jar, which was covered with a piece of a black organza cloth. Each experiment was arranged completely randomized at room temperature of $27 \pm 2{ }^{\circ} \mathrm{C}$. Eggs that were laid on the treated tubers were collected daily for 10 days, and the infested tubers were collected every day up to the end of egg deposition at each treatment. The total number of the deposited eggs/treatment was counted. The infested tubers at each treatment were left to complete larval development, pupation, and emergence of new moths $\left(F_{1}\right)$ after different treatments. For the control treatment, tubers were left without treatments at the same conditions. Biological aspects evaluated were number of deposited egg/treatment, $\%$ of emerged moths $\left(\mathrm{F}_{1}\right)$, and duration of life cycle (egg to adult).

\section{Mean index of tuber damage}

The assessment of the mean index of tuber damages was determined according the following categories based on degree of larval tunneling visible from external examination (Fenemore 1980).

\begin{tabular}{|c|c|c|}
\hline $\begin{array}{l}\text { Infestation } \\
\text { category }\end{array}$ & Damage category & $\begin{array}{l}\text { Weighing } \\
\text { factor }\end{array}$ \\
\hline 1- Clean & No visible of sign infestation & 0 \\
\hline 2- Slight & $\begin{array}{l}\text { One or two mines, which could be } \\
\text { removed readily in peeling. }\end{array}$ & $X_{1}$ \\
\hline $\begin{array}{l}\text { 3- } \\
\text { Moderate }\end{array}$ & $\begin{array}{l}\text { More than two mines present, and up to } \\
\text { one-third of surface showing damage. }\end{array}$ & $X_{2}$ \\
\hline 4- Sever & $\begin{array}{l}\text { More than one-third of the tuber surface } \\
\text { showing damage. }\end{array}$ & $x_{3}$ \\
\hline
\end{tabular}

The maximum possible index was, thus, 30 tunnels/ tuber, if all tubers fall into the severe category according Fenemore (1980).

$$
D I \frac{\text { No.Slight }\left(X_{1}\right)+\text { No.Moderate }\left(X_{2}\right)+\operatorname{No} \text {.Severe }\left(X_{3}\right)}{\text { Total number of tubers }} \times 10
$$

All tests were replicated 10 times under the storage condition $\left(27 \pm 3^{\circ} \mathrm{C}\right)$. 
Persistence of plant powders for protection the tubers from PTM infestation during different storage intervals

The experiment was run under the storage condition; submerged $10-\mathrm{Kg}$ clean potato tubers were dried from being water mixed and shacked well with $250 \mathrm{~g}$ from the tested dried powders, then each treatment was distributed into 10 2-L jars, each contained $1-\mathrm{Kg}$ treated tuber, and 6 newly emerged moths were introduced in each replicate $(3 \hat{\sigma}+3$ q $)$. Percentage of damage index was recorded after different intervals of exposure time $(2,4,6$, 8,10 , and 12 weeks) post-infestation.

\section{Test of potato tubers germination}

One kilogram of the treated tubers from each tested plant powders was left for 2-3 weeks in a damping chamber. The growth of buds or sprouts was recorded.

\section{Statistical analysis}

The mortality rate was corrected, using Abbott (1925) formula. All data were statistically subjected to analysis of variance (ANOVA) through SPSS Computer program, and significantly different means were separated using least significant difference (LSD).

\section{Results}

\section{Effects of the tested plant powders on biological aspects} of PTM

\section{On the egg deposition}

Results in Table 2 cleared a positive effect on the tuber protection from deposited eggs and appearance of new emerged moths $\left(\mathrm{F}_{1}\right)$. As shown in the table, highly significant differences were recorded between each of all treatments and the untreated tubers (control). Colocynth, Zygophyllum, and Coriander plant powders recorded very low numbers $(1.8,2.2$, and 3 eggs), respectively, of deposited eggs on the treated tubers, followed by Senna, Camomile, Harmel, and Jasmine (4.4, 6.4, 7.2, and 7.4), respectively, compared with 29 eggs in the untreated tubers. Solanum and Basil had the moderate effects (11.2 eggs) for both. The respective least protection was found by Mint, Arnolsse and Geranium (16.6, 17.6, and 18.2 eggs), when compared with the control.

\section{On percentage of the emerged moths $\left(F_{1}\right)$}

Data in Table 2 shows that Coriander and Zygophyllum had achieved a complete protection to the tubers, where there were no emerging moths observed from the treated/or infested tubers, followed by Basil, Geranium, Camomile, Arnolosse, Jasmine, and Mint in different percentage of $F_{1}$ of emerged moths (means ranged from 17 to 21 moths). Harmal recorded a moderate effect (52.77\%), followed by Senna, and Colocynth (72.27\%); Solanum had no effect on the developing larvae in the tubers.

\section{On the duration of life cycle}

Results in Table 2 indicated the durations of life cycle of PTM at all treatments (from deposited eggs up to adult emergence). There was no significant effect $(P<0.01)$ on the mean duration of all treatments, except for Colocynths (18.8 day) compared with control (37.6 day).

Table 2 Effect of the tested plant powders on some biological aspects of potato tuber moth (PTM) Phthorimeae operculihha

\begin{tabular}{|c|c|c|c|c|}
\hline \multirow{2}{*}{$\begin{array}{l}\text { Tested plant } \\
\text { powder }\end{array}$} & No. of deposited eggs & \multirow[t]{2}{*}{ Duration of life cycle in days } & \multirow[t]{2}{*}{ No. of emerged moths } & \multirow{2}{*}{$\begin{array}{l}\text { \% Adult } \\
\text { offspring } \\
\text { (F1) }\end{array}$} \\
\hline & Mean \pm SE & & & \\
\hline Coriander & $1.8 \pm 0.66 \mathrm{dc}$ & $0 \mathrm{c}$ & $0 \mathrm{c}$ & 0 \\
\hline Colocynth & $2.2 \pm 0.92 \mathrm{cb}$ & $18.8 \pm 7.59 b$ & $1.6 \pm 0.67 c$ & 72.72 \\
\hline Zyhgophyllum & $3.0 \pm 1.89 \mathrm{cb}$ & $0 \mathrm{c}$ & $0 \mathrm{c}$ & 0 \\
\hline Senna & $4.4 \pm 0.81 \mathrm{cb}$ & $31.2 \pm 2.10 \mathrm{a}$ & $3.4 \pm 1.08 \mathrm{C}$ & 72.27 \\
\hline Camomile & $6.4 \pm 2.54 \mathrm{cb}$ & $35.0 \pm 1.00 \mathrm{a}$ & $1.4 \pm 0.51 \mathrm{C}$ & 18.75 \\
\hline Harmel & $7.2 \pm 1.42 \mathrm{cb}$ & $34.2 \pm 0.20 \mathrm{a}$ & $3.8 \pm 1.07 c$ & 52.77 \\
\hline Jasmine & $7.4 \pm 1.21 \mathrm{cb}$ & $27.0 \pm 6.80 \mathrm{ba}$ & $1.6 \pm 0.67 c$ & 21.62 \\
\hline Basil & $11.2 \pm 2.73 \mathrm{cb}$ & $34.2 \pm 1.96 \mathrm{a}$ & $1.6 \pm 0.6 c$ & 17.39 \\
\hline Solanum & $12.2 \pm 2.22 \mathrm{cb}$ & $34.0 \pm 0.55 a$ & $12.2 \pm 2.2 b$ & 100 \\
\hline Mint & $16.6 \pm 11.49 a b$ & $30.0 \pm 7.5 \mathrm{ab}$ & $3.6 \pm 1.75 c$ & 21.69 \\
\hline Arnoglosse & $17.6 \pm 4.77 \mathrm{ab}$ & $32.6 \pm a .6 a$ & $3.4 \pm 0.67 c$ & 19.32 \\
\hline Geranium & $18.2 \pm 7.17 \mathrm{ab}$ & $31.6 \pm 1.36 \mathrm{a}$ & $3.2 \pm 1.39 c$ & 17.85 \\
\hline Control & $29.0 \pm 7.11 \mathrm{a}$ & $33.6 \pm 0.68 \mathrm{a}$ & $25 \pm 5.86 \mathrm{a}$ & 95.17 \\
\hline LSD0.05 & 13.28 & 11.35 & 5.49 & \\
\hline LSD0.01 & 7.31 & 17.69 & 15.16 & \\
\hline
\end{tabular}

Means with the same letters are not significantly different in vertical column $P<0.05$ 
Data also shows significant differences in decreasing the number of emerged adults from the treated tubers, ranged from complete protection caused by Coriander and Zygophyllum (0) to 1.4-12.2 moth for all the other tested plant powders than 25.6 moth in the control. All the tested powders cleared a reduction in the insect development and played a role as growth regulators.

\section{Damage index of potato tubers treated with plant powders}

All tested plant powders recorded highly significant difference $(P<0.01)$ (Table 3$)$. The high protection was caused by Coriander and Zygophyllum, as they gave a complete protection to the treated tubers (zero DI) for both. All the other treatments showed variable degrees of DI, ranged from 8.78 to 20 compared with 30 in the control.

\section{Persistence of plant powders along the storage periods} Damage index percentage in Table 4 cleared that Coriander and Zygophyllum introduced a complete protection to the treated tubers continuously, 10 weeks of storage, where no infestation was observed, but damage increased gradually at the beginning of the 12th week, with a small percentage of DI (6.5 and 6.8) compared with that of control (30). On other plant powders, in the second week of infestation, DI was 8.78 for Colocynth and 20 for Arnoglosse; then, the damage increased gradually till reaching 18 and 24, respectively, in the12th week from storage as no protection was

Table 3 Damage index (DI) of potato tubers treated with different plant powders

\begin{tabular}{ll}
\hline Tested plant powders & $\begin{array}{l}\text { Tuber damage index } \\
\text { (Mean } \pm \text { SE) }\end{array}$ \\
\hline Coriander & $0 \mathrm{~h}$ \\
Zyhgophyllum & $0 \mathrm{~h}$ \\
Colocynth & $8.78 \pm 0.85 \mathrm{~g}$ \\
Jasmine & $11.34 \pm 0.63 \mathrm{f}$ \\
Mint & $13.33 \pm 0.76 \mathrm{e}$ \\
Basil & $15.00 \pm 1.00 \mathrm{de}$ \\
Camomile & $15.00 \pm 1.73 \mathrm{de}$ \\
Geranium & $16.56 \pm 0.91 \mathrm{~cd}$ \\
Senna & $17.36 \pm 0.64 \mathrm{c}$ \\
Harmel & $18.50 \pm 0.50 \mathrm{~b} \mathrm{bc}$ \\
Solanum & $20.00 \pm 1.00 \mathrm{~b}$ \\
Arnoglosse & $20.00 \pm 2.00 \mathrm{~b}$ \\
Control & $30.00 \pm 0.00 \mathrm{a}$ \\
LSD 0.05 & 1.78 \\
LSD 0.01 & 2.24 \\
\hline
\end{tabular}

noticed. No protection after $12^{\text {th }}$ week of storage at all the tested powders.

\section{Tuber germination}

Observations showed that all treatments had no effects on the germination of tubers, where the buds or sprouts appeared on all the treated tubers after 2-3 weeks, when tubers were kept in a humid place.

\section{Discussion}

Obtained data agree with other studies related to the tuber protection by plant powders and their inhibition or decreasing of eggs. The olfactory and contact chemo receptors that were located on the ovipositor, tarsus, and antennae were repelled by the odor of volatile or chemical constituents of the plant powder (Sharaby et al. 2002). Plant odor acts as feeding and oviposition deterrents to a wide variety of insect pests. It was also effective as a fumigant (Koul et al. 2008). Failure of egg hatching was due to the inhibition of embryonic development rather than acute toxicity of the plant powder (Saxena and Sharma (1972), on embryonic inhibition in Aedes egypti by volatile oils. Rivera and Retamoza (2000) mentioned that reduction in oviposition may have been induced by change in appearance of the treated crops thus making the crops unattractive to the insect. Egg-laying inhibition, which is significant, is responsible for low crop damage, probably due to egg-laying deterrent effects of some plant powders. Most insects' breathe through the trachea, which usually leads to the opening of their spiracle, and these spiracles might be blocked by the powders, thereby leading to suffocation (Komabonta and Falodu 2013).

Sharaby (1988) mentioned that reproduction in the PTM was significantly reduced when either males or females were exposed to the vapor of orange peel oil. In addition, a pronounced reduction in egg production and egg viability occurred when the moths were exposed to the odors arising from plant oils. Sharaby et al. (2014) reported that dusting potato tubers with bulb powder of Allium cepa (50\% conc. mixed with talcum powder) displayed a highly effective role in the reduction of deposited eggs as well as adult emergence there from Allium cepa. Pelargonium graveolens and Cymbopogon citrates oils caused a high reduction in larval penetration into treated tubers.

Present results agree with some other investigations (Raman and Booth 1986; Lal 1987) who stated that PTM tubers infestation can be minimized by covering the tubers with Lantana camara L., L. aculeate, and Eucalyptus globules plant powders. Rivera and Retamoza (2000) reported some plants Minthostachys spp., E. globules, Baccharis spp., L. camara, Chenopodium botrys, Mentha arvensis, Artemesi vulgaris, and 
Table 4 Persistence of plant powders in protection potato tubers from PTM Phthorimaea operculella infestation during different intervals of storage

\begin{tabular}{|c|c|c|c|c|c|c|}
\hline \multirow[t]{2}{*}{ Plant powders } & \multicolumn{6}{|c|}{$\begin{array}{l}\text { Tuber damage index (DI) at intervals in weeks } \\
\text { Mean } \pm \text { SE }\end{array}$} \\
\hline & 2nd & 4th & 6th & 8th & 10th & 12th \\
\hline Zyhgophyllum & $\mathrm{Oh}$ & $\mathrm{Oh}$ & $\mathrm{Oh}$ & $\mathrm{Oh}$ & $4.80 \pm 0.6 f$ & $6.50 \pm 0.28 b$ \\
\hline Coriander & $\mathrm{Oh}$ & $\mathrm{Oh}$ & $\mathrm{Oh}$ & $\mathrm{Oh}$ & $6.80 \pm 0.17 f$ & $6.80 \pm 0.44 b$ \\
\hline Colocynth & $8.78 \pm 0.49 \mathrm{~g}$ & $9.35 \pm 0.30 \mathrm{~b}$ & $15.00 \pm 1.00 f$ & $16.67 \pm 0.67 \mathrm{e}$ & $18.00 \pm 1.15 \mathrm{e}$ & $29.96 \pm 0.03 a$ \\
\hline Jasmine & $11.40 \pm 0.36 f$ & $12.00 \pm 10.05 \mathrm{~g}$ & $16.05 \pm 2.03$ ef & $19.00 \pm 0.05$ de & $20.05 \pm 0.53$ de & $29.98 \pm 0.02 a$ \\
\hline Mint & $13.33 \pm 0.44 \mathrm{ed}$ & $13.83 \pm 0.17 f$ & $15.33 \pm 0.33 f$ & $17.00 \pm 1.00 \mathrm{e}$ & $17.33 \pm 1.33 \mathrm{e}$ & $29.60 \pm 0.32 a$ \\
\hline Basil & $15.00 \pm 0.58 d$ & $15.67 \pm 0.33 \mathrm{e}$ & $16.66 \pm 0.53 \mathrm{de}$ & $18.90 \pm 0.67 \mathrm{de}$ & $19.33 \pm 0.88 \mathrm{de}$ & $29.97 \pm 0.33 a$ \\
\hline Camomile & $15.00 \pm 1.00 \mathrm{~d}$ & $16.00 \pm 0.67 \mathrm{e}$ & $16.67 \pm 0.67 \mathrm{e}$ & $18.70 \pm 0.36$ de & $21.33 \pm 1.86 \mathrm{de}$ & $29.59 \pm 0.05 a$ \\
\hline Geranium & $16.60 \pm 0.53 \mathrm{~cd}$ & $17.47 \pm 0.23 d$ & $18.23 \pm 0.91 \mathrm{~cd}$ & $22.00 \pm 1.70 \mathrm{bc}$ & $22.33 \pm 1.5 b c$ & $29.99 \pm 0.07 a$ \\
\hline Senna & $17.36 \pm 0.37 c$ & $18.07 \pm 0.33 \mathrm{~cd}$ & $19.67 \pm 0.33 b c$ & $21.33 \pm 0.67 b c$ & $21.33 \pm 0.66 b c$ & $29.99 \pm 0.01 a$ \\
\hline Harmel & $18.52 \pm 0.29 b c$ & $18.76 \pm 0.03 c$ & $19.00 \pm 0.58 b c$ & $19.67 \pm 0.33 \mathrm{~cd}$ & $20.33 \pm 0.88 \mathrm{~cd}$ & $29.80 \pm 0.17 a$ \\
\hline Solanum & $20.00 \pm 0.58 b$ & $20.00 \pm 0.00 \mathrm{~b}$ & $20.67 \pm 0.67 b c$ & $21.30 \pm 0.67 b c$ & $22.33 \pm 1.45 b c$ & $29.99 \pm 0.01 \mathrm{a}$ \\
\hline Arnoglosse & $20.00 \pm 1.50 \mathrm{~b}$ & $20.67 \pm 0.67 b$ & $21.33 \pm 0.67 b$ & $23.00 \pm 1.00 \mathrm{~b}$ & $24.00 \pm 1.00 \mathrm{~b}$ & $29.99 \pm 0.00 \mathrm{a}$ \\
\hline Control & $30.00 \pm 0.00 \mathrm{a}$ & $30.00 \pm 0.00 \mathrm{a}$ & $30.00 \pm 0.00 \mathrm{a}$ & $30.00 \pm 0.00 \mathrm{a}$ & $30.00 \pm 0.00 \mathrm{a}$ & $30.00 \pm 0.00 \mathrm{a}$ \\
\hline LSD 0.05 & 1.78 & 0.81 & 2.52 & 2.34 & 3.07 & 0.58 \\
\hline LSD 0.01 & 2.42 & 1.10 & 3.43 & 3.24 & 1.14 & 0.79 \\
\hline
\end{tabular}

Means with the same letters are not significantly different in vertical column $(P<0)$

Lycopersicom hirsutum were efficient to PTM control. Dried powders of rhizomes of Acorus calamus, leaves of Melia azedarach, ripened berries of Pper longum, leaves of Prunus persica, and ripened fruit of Lindera neesiana were tested as treatments for the control of PTM in the laboratory (Niroula and Vaidya 2004). Kashyap et al. (1992) tested the powder of dried leaves of Cannabis sativa and reported longer than 120 days save in the storage. Dry leaves of E.globules in powder form showed a high efficiency in controlling the PTM damage in potatoes stored for 4 months in Peru (Raman and Booth 1986). Damage of PTM can be drastically reduced by covering tubers with small cover of leaves of camara (Lal 1987). Sharaby et al. (2009) mentioned that dried plant parts (leaves, fruits and seeds) of 14 different plants were tested in different concentrations with talcum powder against oviposition of pests. The results indicated that dried Allium cepa, Curcuma longa, Colocasia antiquarum, Ocinum basilicum, Dodonea viscose, and Thuja orientalis had a highly significant role in reducing oviposition. Sisay and Ibrahim (2012) concluded that L. camara, E. globulusi, and Pyrethrum flowers can be used to protect seed potatoes from PTM damage in storage. Aziza and Asma (2015) reported the effectiveness of some plant powders in pest control.

\section{Conclusion}

The study results showed that the 12 tested plant powders, at the rate of $25 \mathrm{~g}$ plant powder per $1 \mathrm{Kg}$ of potato tubers, could protect the tubers from PTM infestation for more than 8 weeks during storage. The most potent powders were Coriander and Zygophyllum that reduced the survival of Ph. operculella. Therefore, the tested plant powders can be considered as good alternatives of the synthetic chemicals for insect control without any effects on tubers germination.

Funding

The experimental work is not funded financially by any agency.

\section{Availability of data and materials}

All data on which abstracted of the study have been drawn are presented in the main manuscript.

\section{Significant statements}

An eco-friendly approach can be followed for sustainable development of the nature and its dependence. It can be concluded that the tested plant powders have high potential as natural protector to the stored potatoes against TPM.

\section{Author declaration}

All authors declare that the manuscript has not been sent for consideration for publication or for publication anywhere else before; the manuscript is an original research data.

\section{Authors' contributions}

ASH suggested the research idea, designed the experiments, wrote the manuscript, reviewed the data, and edited and approved the manuscript. SBF made the experiments, recorded and analyzed the data, prepared the tables, assisted in the write up of the manuscript, and approved the manuscript. Both authors read and approved the final manuscript.

Ethics approval and consent to participate Not applicable.

Consent for publication

Not applicable. 


\section{Competing interests}

The authors declare that they have no competing interests.

\section{Publisher's Note}

Springer Nature remains neutral with regard to jurisdictional claims in published maps and institutional affiliations.

\section{Author details}

'Pests and Plant Protection Department Agricultural \& Biological Researches Division, National Research Centre, Cairo, Egypt. ${ }^{2}$ Biology Department College of Science, Imam Abdel Rahman Bin Faisal University, Dammam, Kingdom of Saudi Arabia.

Received: 8 March 2019 Accepted: 17 April 2019

Published online: 22 May 2019

\section{References}

Abbott WS (1925) A method of computing the effectiveness of insecticide. J Eccol Entomol 18:265-267

Aziza A, Asma E (2015) Evaluation of some plant essential oils against the black cutworm Agrotis iosiolon. Glob J Adv Res 2(4):701-711

Chandel BS, Dubey I, Tewari A (2018) Screening of plant extract for insecticidal biopotancy against Callosobrucus chinensis L. (Colioptera: Bruchidae) on chickpea, Cicer aritenum L. Int J Entomol Res 3(1):101-106

EL-Sherif ARA (1966) Studies on the morphology and biology of the potato tuber moth Phthorimaea operculella (Zeller) M. Sc. Thesis. Agric. Cairo. Univ. 97 p

Fenemore PG (1980) Oviposition of potato tuber moth Phthorimaea oprculell (Zell.) (Lepidoptera: Geleshiidae) identification of host plant factors influencing oviposition response. NZJ Zool 7:435-439

Kashyap NP, Bhagat RM, Sharma DC, Suri SM (1992) Efficacy of some useful plant leaves for the control potato tuber moth, Phthorimaea operculella Zell. In stores. J Ent Res 16:223-227

Khan MA, Gumbs FA (2003) Repellent effect of Ackee (Blighia sapida Koenig) component fruit parts against stored product insect pests. J Trop Agric 80 : 19-27

Komabonta KA, Falodu BB (2013) Bioefficacy of three plant products as postharvest grain Sitophillus oryzae Linnacus (Coleoptera: Curculionidae) on stored wheat (Triticum aestivum). Int J Sci Nature 4(2):259-264

Koul OS, Walia G, Dhaliwal GS (2008) Essential oils as green pesticides: potential and constrains. Biopesticides Int 4(1):63-84

Lal L (1987) Studies on natural repellents against potato tuber moth Phthorimaea operculella (Zeller) in country stores. Potato Res 30(2):329-334

Meyer- Baron M, Knapp G, Schaper M, Van Thriel C (2015) Meta-analysis on occupational exposure to pesticides-neyrobehavioral impact and doseresponse relationships. Environ Res 136:234-245

Migahed AM (1996) Flora of Saudi Arabia, Fourth ed. King Saud University Press, Riyadh

Niroula SP, Vaidya K (2004) Efficacy of some botanicals against potato tuber moth Phthorimaea operculella (Zeller, 1773). Our Nature 2:21-25

Onu FM, Ogu E, Ikehi ME (2015) Use of neem and garlic dried plant powders for controlling some stored grains pests. Egyptian J Biol Pest Contr 25(2):507-512

Owusu EO (2001) Effects of some Ghanaian plant components on control of two stored product insect pests of cereals. J Stored Prod Res 37:85-91

Quignard EIJ, Pohlit AM, Numomura SM, Pinto ACS, Santoos EVM, Morais SKR (2003) Screening of plants found in Amazonas state for lethality towards brine shrimp. Acta Amazon 33:93-104

Raman KV, Booth RH (1986) Control of potato tuber moth, Phthorimaed operculella (Zeller) in rustic potato stores of Peru. Am Potato J (USA) 63: 449-450

Rivera NC, Retamoza RC (2000) Potato moth control with local plants in the storage of potato. In: Stoll G (ed) Natural crop protection in the tropic. Margraf Verlage, Weikersheim, pp 313-320

Rondon SI (2010) The potato tuber worm: a literature review of its biology, ecology, and control. Am J Pot Res 87:149-166

Saxena KN, Sharma RN (1972) Embryonicinhibition and oviposition induction in Aedes egypti by certain terpenoides. J Econ Entomol 65(6):1588-1591

Shaalan EAS, Canyon D, Younes MWF, Abdel-Wahab H, Mansour AH (2005) A review of botanical phytochmicals with mosquitocidal potential. Environ Int 31:1149-1164

Sharaby A (1988) Effect of orange, Citrus sinensis (L.) peel oil on reproduction in Phthorimaea operculella (Zeller). Insect Sci Appl 9:201-203
Sharaby A, Abdel Rahman H, Abdel-Aziz SH, Moawad SS (2014) Natural plant oils and terpenes as protector for the potato tubers against Phthorimaea operculella infestation by different application methods. Egyptian J Biol Pest Contr 24(1):265-274

Sharaby A, Abdel Rahman HA, Moawad S (2002) Sensors of the potato tuber moth Phthorimaea operculella (Zeller) (Lepidoptera:Geleshiidae). Bull NRC Egypt 27(1):131-147

Sharaby A, Abdel-Rahman H, Moawad S (2009) Biological effects of some natural and chemical compounds on the potato tuber moth, Phthorimeae operculell Zell. (Lepidoptera: Gelechiidae). Saudi J Biol Sci 16:1-9

Sisay A, Ibrahim A (2012) Evaluation of some potential botanicals to control potato tuber moth, (Phthorimaea operculella) under storage condition at Bako. Western Ethiopia. Int J Phytopathol 2312(1):14-18

Yuan Y, Chen C, Zheng C, Wang X, Yang G, Wang Q, Zhang Z (2014) Residues of chlorpyrifos and cypermethrin in vegetables and probabilistic exposure assessment for consumers in Zhejiang Province, China. Food Control 36:63-68

\section{Submit your manuscript to a SpringerOpen ${ }^{\circ}$ journal and benefit from:}

- Convenient online submission

- Rigorous peer review

- Open access: articles freely available online

- High visibility within the field

- Retaining the copyright to your article

Submit your next manuscript at $\boldsymbol{\nabla}$ springeropen.com 